\title{
NUMBER OF RECOMBINATIONS AND GENETIC PROPERTIES OF A MAIZE POPULATION UNDERGOING RECURRENT SELECTION
}

\author{
Francisco Pinheiro Lima Neto ${ }^{1}$; Cláudio Lopes de Souza Júnior ${ }^{2 *}$ \\ ${ }^{1}$ USP/ESALQ - Programa de Pós-Graduação em Genética e Melhoramento de Plantas. \\ ${ }^{2}$ USP/ESALQ - Depto. de Genética, C.P. 83 - 13400-970 - Piracicaba, SP - Brasil. \\ *Corresponding author $<$ clsouza@esalq.usp.br>
}

\begin{abstract}
In maize recurrent selection programs, selected genotypes were recombined once to generate genetic variability for the next selection cycle. Selection generates negative gametic phase disequilibrium which reduces genetic variances, and this disequilibrium is not significantly reduced with only one generation of recombination. The objective of this research was to assess the effects of one additional generation of recombination on phenotypic and genotypic parameters in a maize population undergoing recurrent selection. Selected progenies of the EPB-4 population were subjected to one and two generations of recombination, and from each generation half- and full-sib progenies were developed and evaluated at three environments for grain yield, plant and ear heights, prolificacy, and ear placement. There were no significant changes between each progeny type with one and two generations of recombination for the means, ranges, phenotypic distribution of the traits, genetic variances, heritability coefficients, and genetic correlations for the traits assessed. The results suggest that an additional generation of recombination will not increase the effectiveness of maize recurrent selection programs.
\end{abstract}

Key words: maize improvement, heritability coefficients, genetic correlations

\section{NÚMERO DE RECOMBINAÇÕES E AS PROPRIEDADES GENÉTICAS DE UMA POPULAÇÃO DE MILHO SOB SELEÇÃO RECORRENTE}

\begin{abstract}
RESUMO: Nos programas de seleção recorrente, os genótipos selecionados são recombinados uma vez para gerar variabilidade genética para o próximo ciclo de seleção. A seleção gera desequilíbrio negativo na fase gamética, reduzindo as variâncias genéticas, e este desequilíbrio não é significantemente reduzido com apenas uma geração de recombinação. O objetivo desta pesquisa foi avaliar os efeitos de uma geração adicional de recombinação sobre parâmetros fenotípicos e genéticos em uma população de milho submetida à seleção recorrente. Progênies selecionadas da população EPB-4 foram recombinadas por uma e duas gerações, e de cada geração foram obtidas progênies de meios-irmãos e de irmãos germanos, as quais foram avaliadas em três ambientes para produção de grãos, altura da planta e da espiga, prolificidade e posição da espiga. Não foram detectadas alterações significativas entre cada tipo de progênie com uma e duas gerações de recombinação para as médias, intervalos de variação, distribuição fenotípica dos caracteres, variâncias genéticas, coeficientes de herdabilidade e correlações genéticas para os caracteres avaliados. Os resultados sugerem que uma geração adicional de recombinação não aumentará a eficiência dos programas de seleção recorrente em milho.

Palavras-chave: melhoramento de milho, coeficientes de herdabilidade, correlações genéticas
\end{abstract}

\section{INTRODUCTION}

Recurrent selection is a cyclical breeding procedure designed to improve the performance of populations while maintaining genetic variability for continued selection. Reported results have shown that recurrent selection has been highly effective in maize (Zea mays L.) to improve both populations per se and population cross performances (Hallauer et al., 1988;
Rezende \& Souza Júnior, 2000; Souza Júnior \& Pinto, 2000 ), and also to develop improved single-crosses (Betrán \& Hallauer, 1996). Recurrent selection programs are designed to be conducted for a long-term, and thus the maintenance of genetic variability of the populations is of paramount importance since it will determine the magnitude of the responses to selection and the number of selection cycles that could be conducted. Thus, to generate genetic variability the selected 
genotypes are recombined once in the last phase of each recurrent selection cycle (Hallauer, 1985).

Selection generates negative gametic phase disequilibrium for linked and unlinked loci, which reduces the genetic variances of the traits under selection, and the disequilibrium is halved at each generation of recombination for unlinked loci, whereas it persists for longer for linked loci (Bulmer, 1980). Hence, only one generation of recombination in each selection cycle is not enough to dissipate the effects of the linkage disequilibrium even for unlinked loci, and then these effects should increase after several cycles, reducing the response to selection and the number of selection cycles.

Despite the importance of recombination of the selected genotypes to generate genetic variability in maize recurrent selection programs, to the authors' knowledge there are no information on the effects of an additional generation of recombination on the magnitudes of both means and genetic variances. Thus, the objective of this study was to investigate whether an additional generation of recombination in a maize recurrent selection program affect the means, the genetic variances and the phenotypic distribution of the traits.

\section{MATERIALAND METHODS}

\section{Genetic materials}

Maize EPB-4 population used for this research was developed from the recombination of selected progenies from the third cycle of reciprocal recurrent selection with EPB-5 population. EPB-4 is an earlyflowering with yellow dent kernels population. Three cycles of selection were conducted using 200 interpopulation half-sib and $S_{1}$ progenies as selection and recombination units, respectively, and at each cycle $10 \%$ of selection intensity was applied, i.e., 20 out of 200 progenies evaluated were selected. The $\mathrm{S}_{1}$ progenies were recombined as follows: a small bag with only one seed of each selected progeny (20 seeds) were set up and replicated 200 times; each bag was used to sow a row, and within each row pollination was made using a plant either as male or female; so that each selected progeny was represented by 200 plants. After harvest 20 seeds from each pollinated ear were taken and bulked to give rise to the improved population.

After recombination of the third selection cycle (1990/1991 agricultural season), a second generation of recombination was obtained as follows: 600 seeds from the first recombination were grown and each plant was used either as male or female for pollinization, and 20 seeds from each of 300 pollinated ears were bulked to give rise to the second generation of recombination. In 1991/1992 agricultural season 500 plants from the first and 500 plants from the second generation of recombination were grown and 100 half-sib and 100 fullsib intrapopulation progenies were produced at random in each generation of recombination. Hereafter these progenies will be identified as HS-1 and HS-2 for halfsib progenies, and FS-1 and FS-2 for full-sib progenies from the first and the second generation of recombination, respectively. Half-sib and full-sib progenies were developed since they are commonly used in recurrent selection programs.

\section{Experimental procedures}

The 400 progenies were allocated in four 10 $\times 10$ lattices, with 25 progenies from each type and generation in each lattice; i.e., sets of 25 progenies of HS-1, HS-2, FS-1, and FS-2 were included in each lattice. The four experiments were evaluated at three environments with two replications per environment, and environment refers to the combination of agricultural season and location. The experiments were evaluated at the Experimental Station of Caterpillar in 1992/ 1993 and in 1993/1994, and at the Experimental Station of Areão in 1992/1993 agricultural seasons; these experimental stations are near Piracicaba $\left(22^{\circ} 42^{\prime} \mathrm{S}\right.$; $47^{\circ} 37^{\prime}$ W), São Paulo State, Brazil. The experiments were grown in adjacent areas, and the replications of each lattice were randomized in the experimental area. Plots were one row $4 \mathrm{~m}$ long and spaced $1 \mathrm{~m}$ between rows, and they were overplanted and thinned to 20 plants per row $\left(\approx 50,000\right.$ plants $\left.\mathrm{ha}^{-1}\right)$. Data for grain yield (g per plant), grain moisture $\left(\mathrm{g} \mathrm{kg}^{-1}\right)$, stand (plants per plot), plant height (cm per plant), and ear height (cm per plant) were recorded in all environments. Plant and ear heights were recorded in five competitive plants per plot, from the ground level to the collar of the flag leaf and to the uppermost ear node, respectively; and the plot means were used for analysis. Ear placement was recorded per plot by the ratio mean ear height/ mean plant height. Grain yield of each plot were adjusted for average stand by covariance analysis and to $155 \mathrm{~g} \mathrm{~kg}^{-1}$ of grain moisture.

\section{Statistical analyses}

Analyses of variance and covariance were computed for each lattice, and the adjusted entry means and effective error mean squares and mean products were used to compute the combined analyses of variance and covariance across environments. The sum of squares and the sum of products of the progeny source of variation was partitioned into HS1, HS-2, FS-1, FS-2 progenies, and among groups; the progeny $\times$ environment sum of squares and sum of products were partitioned accordingly. As all effects 
of the mathematical model were considered random, except the mean, each type of progeny was tested against its respective partitioned progeny $\times$ environment interaction, and the partitioned progeny by environment interactions were tested against the error mean squares in the $F$ tests. All analyses were performed using the SAS software, Proc GLM (SAS Institute, 2004). Distribution histograms from the means of the progenies were tested for normality by using Shapiro-Wilk $W$ test (Shapiro \& Wilk, 1965). Coefficients of skewness and kurtosis were also computed for each distribution (Snedecor \& Cochran, 1989).

The combined analyses of variance and covariance were used to estimate the genetic variances and the genetic covariances between traits for each progeny type using the method of moments (Searle et al., 1992); i.e., the mean squares and the mean products of each progeny type were equated to its respective expectation and estimates of components of variance and covariance for each progeny type were computed. Estimates of heritability coefficients on a progeny-mean basis, genetic correlations between traits, and $t$ tests for genetic correlations were computed following the procedures described by Vencovsky \& Barriga (1992). Confidence intervals at the 0.95 probability level for the estimates of the components of variance and of heritability coefficients were estimated following the procedures of Burdick \& Graybill (1992). Heritability coefficients and genetic variances were regarded as significantly different from zero whenever the lower bound of their confidence intervals did not bracket negative values or zero. Also, differences between progeny types for estimates of means, genetic variances and of heritability coefficients were regarded as non-significant whenever an estimate of these parameters from one progeny type was not included within the confidence interval of the other progeny type.

\section{RESULTS AND DISCUSSION}

Highly significant differences $(p \leq 0.01)$ in the combined analyses of variance were detected for the two types of progenies subjected to one and two generations of recombination for grain yield, plant height, and ear height; for prolificacy only HS-1 and FS-2 progenies were significant $(p \leq 0.05)$ and highly significant, respectively; and for ear placement only the variation among HS-1 progenies was significant. Progeny by environment interaction was significant only for FS-1 for grain yield, for HS-2 and FS-1 for prolificacy, for HS-1 for ear height, and for FS-1 and FS-2 for ear placement. Thus, there were genetic variability for all types of progenies for grain yield, plant height and ear height, but for prolificacy and ear placement genetic variability was detected only for two and one progeny types, respectively. Progeny by environment interaction was not detected for all types of progenies and for all traits; there were inconsistencies among progeny types and traits, although highly differences were detected among environments for three of the four traits evaluated (Table 1).

The means of all traits for the half-sib and fullsib progenies with one and two generations of recombination did not differ; then, the average of the progenies with one generation of recombination did not differ from the average of the progenies with two generations of recombination. One additional generation of recombination did not change the means of the two types of progenies (Table 2). These results agree with the theory presented by Bulmer (1980) who stated that once selection was relaxed the means of traits would not change if the population was random-mated, i.e., recombined. Also, as expected since the genetic variance of full-sib is greater than that of half-sib progenies (Hallauer \& Miranda Filho, 1988), the ranges of the full-sib progenies were larger than the ranges of the half-sib progenies and for each progeny type the ranges did not differ significantly between the generations of recombination.

The distribution of the half- and full-sib progeny means with one and two generations of recombination were normal ( $W$ test non-significant), and skewness and kurtosis were non-significant for all traits evaluated, except for prolificacy for HS-1 and HS-2 progenies in which skewness and kurtosis were positive and highly significant $(p \leq 0.01)$ indicating that these distributions had elongated upper tails and longer tails than expected under normality (tests not shown). Thus, an additional generation of recombination did not change the normality of the distributions of the two types of progenies, except for prolificacy for the halfsib progenies. Reported results of several cycles of recurrent selection have shown that for most of the traits their distribution remained normal throughout the selection cycles, indicating that selection followed by only one generation of recombination did not affect the distribution of the traits (Rezende \& Souza Júnior, 2000; Santos et al., 2005). Then, one could expect that one additional generation of recombination would not affect the distribution of the traits.

Estimates of genetic variances of half-sib and full-sib progenies with one and two generations of recombination differed from zero $(p \leq 0.05)$ for all traits evaluated, except for prolificacy for HS-2 progenies. The estimates of genetic variances of full-sib progenies for all traits were larger than that of half-sib progenies, except for HS-1 for ear placement. These results were expected because the genetic variance of full-sib prog- 
Table 1 - Values and significances of the mean squares from the analyses of variances for several traits.

\begin{tabular}{|c|c|c|c|c|c|c|}
\hline \multirow{2}{*}{ Source of variation ${ }^{a}$} & \multirow{2}{*}{ df } & \multicolumn{5}{|c|}{ Mean Squares } \\
\hline & & Grain yield & Prolificacy $^{\mathrm{b}}$ & Plant height & Ear height & Ear placement ${ }^{c}$ \\
\hline & & $\mathrm{g}$ per plant & ears per plant & $\ldots \ldots c m p$ & lant --.--- & \\
\hline Environments (Env.) & 8 & $90,725.99 * *$ & $33.47^{\mathrm{ns}}$ & $30,237.87 * *$ & $40,006.90 * *$ & $2,980.68 * *$ \\
\hline Replications/Env. & 12 & $2,245.11 * *$ & $13.09 * *$ & $3,158.30 * *$ & $197.94 *$ & $125.25 * *$ \\
\hline Progenies & 396 & $1,462.48 * *$ & $4.37 *$ & $391.48 * *$ & $205.99 * *$ & $11.60 * *$ \\
\hline HS- 1 & 96 & $1,313.68 * *$ & $3.42 *$ & $288.95^{*}$ & $174.93 * *$ & $12.32 * *$ \\
\hline HS-2 & 96 & $1,158.85 * *$ & $3.21^{\mathrm{ns}}$ & $351.49 * *$ & $157.05 * *$ & $6.83^{\mathrm{ns}}$ \\
\hline FS-1 & 96 & $1,724.57 * *$ & $5.58^{\mathrm{ns}}$ & $486.86 * *$ & $233.83 * *$ & $11.21^{\mathrm{ns}}$ \\
\hline FS-2 & 96 & $1,608.61 * *$ & $5.53 * *$ & $433.00 * *$ & $220.66 * *$ & $12.09^{\mathrm{ns}}$ \\
\hline Among groups (AG) & 12 & $1,816.38^{\mathrm{ns}}$ & $2.17^{\mathrm{ns}}$ & $436.57^{\mathrm{ns}}$ & $505.87 * *$ & $42.96^{*}$ \\
\hline Progenies $\times$ Env. & 792 & $665.24 *$ & $3.61 * *$ & $190.54^{\mathrm{ns}}$ & $104.67 * *$ & $8.37 *$ \\
\hline HS-1 1 Env & 192 & $573.27^{\mathrm{ns}}$ & $2.40^{\mathrm{ns}}$ & $195.47^{\mathrm{ns}}$ & $117.79 * *$ & $8.16^{\mathrm{ns}}$ \\
\hline HS- $2 \times$ Env & 192 & $669.96^{\text {ns }}$ & $3.92 * *$ & $212.63^{\mathrm{ns}}$ & $95.50^{\mathrm{ns}}$ & $6.55^{\mathrm{ns}}$ \\
\hline FS-1 $1 \times$ Env & 192 & $718.47 *$ & $4.36 * *$ & $163.87^{\mathrm{ns}}$ & $97.67^{\mathrm{ns}}$ & $8.66^{*}$ \\
\hline FS-2 $\times$ Env & 192 & $675.44^{\mathrm{ns}}$ & $3.43^{\mathrm{ns}}$ & $170.40^{\mathrm{ns}}$ & $100.14^{\mathrm{ns}}$ & $9.17 *$ \\
\hline $\mathrm{AG} \times$ Env & 24 & $855.73^{\mathrm{ns}}$ & $6.08 * *$ & $348.77 * *$ & $165.41 *$ & $15.83 * *$ \\
\hline Error & 972 & 583.91 & 3.06 & 193.54 & 93.84 & 7.29 \\
\hline $\mathrm{CV}(\%)$ & & 15.94 & 16.42 & 6.22 & 8.02 & 5.01 \\
\hline Overall means & & 151.60 & 1.07 & 223.81 & 120.79 & 0.54 \\
\hline
\end{tabular}

${ }^{a}$ All sources of variation were nested within experiments; HS-1 and HS-2, and FS-1 and FS-2 refer to half-sib and full-sib progenies with one and two generations of recombination, respectively. ${ }^{b}$ Mean squares multiplied by $10^{2}$. ${ }^{\mathrm{c}}$ Mean squares multiplied by $10^{4}$.

Table 2 - Half-sib and full-sib progeny means and confidence intervals (between brackets) of the traits evaluated with one and two generations of recombination.

\begin{tabular}{|c|c|c|c|c|c|}
\hline \multirow{2}{*}{$\begin{array}{l}\text { Progeny/ } \\
\text { Recombination }\end{array}$} & \multicolumn{5}{|c|}{ Traits $^{\mathrm{b}}$} \\
\hline & Grain yield & Prolificacy & Plant height & Ear height & Ear placement \\
\hline & g per plant & Ears per plant & $\mathrm{cm} \mathrm{p}$ & lant $\ldots$ & \\
\hline HS-1 & $\begin{array}{c}152.93 \\
{[133.65 ; 172.21]}\end{array}$ & $\begin{array}{c}1.07 \\
{[0.95 ; 1.19]}\end{array}$ & $\begin{array}{c}223.92 \\
{[212.67 ; 235.17]}\end{array}$ & $\begin{array}{c}121.44 \\
{[112.71 ; 130.17]}\end{array}$ & $\begin{array}{c}0.54 \\
{[0.52 ; 0.56]}\end{array}$ \\
\hline HS-2 & $\begin{array}{c}150.93 \\
{[130.09 ; 171.77]}\end{array}$ & $\begin{array}{c}1.06 \\
{[0.90 ; 1.22]}\end{array}$ & $\begin{array}{c}223.64 \\
{[211.90 ; 235.38]}\end{array}$ & $\begin{array}{c}119.82 \\
{[111.95 ; 127.69]}\end{array}$ & $\begin{array}{c}0.53 \\
{[0.51 ; 0.55]}\end{array}$ \\
\hline FS- 1 & $\begin{array}{c}154.64 \\
{[133.06 ; 176.22]}\end{array}$ & $\begin{array}{c}1.07 \\
{[0.90 ; 1.24]}\end{array}$ & $\begin{array}{c}224.94 \\
{[214.64 ; 235.24]}\end{array}$ & $\begin{array}{c}122.02 \\
{[114.06 ; 129.98]}\end{array}$ & $\begin{array}{c}0.54 \\
{[0.52 ; 0.56]}\end{array}$ \\
\hline FS-2 & $\begin{array}{c}147.89 \\
{[126.97 ; 168.81]}\end{array}$ & $\begin{array}{c}1.06 \\
{[0.91 ; 1.21]}\end{array}$ & $\begin{array}{c}222.73 \\
{[212.22 ; 233.24]}\end{array}$ & $\begin{array}{c}119.87 \\
{[111.81 ; 127.93]}\end{array}$ & $\begin{array}{c}0.54 \\
{[0.52 ; 0.56]}\end{array}$ \\
\hline$(\mathrm{HS}-1+\mathrm{FS}-1) / 2$ & $\begin{array}{c}153.78 \\
{[133.32 ; 174.24]}\end{array}$ & $\begin{array}{c}1.07 \\
{[0.92 ; 1.22]}\end{array}$ & $\begin{array}{c}224.43 \\
{[213.64 ; 235.22]}\end{array}$ & $\begin{array}{c}121.73 \\
{[113.37 ; 130.09]}\end{array}$ & $\begin{array}{c}0.54 \\
{[0.52 ; 0.56]}\end{array}$ \\
\hline$(\mathrm{HS}-2+\mathrm{FS}-2) / 2$ & $\begin{array}{c}149.40 \\
{[128.52 ; 170.28]}\end{array}$ & $\begin{array}{c}1.06 \\
{[0.91 ; 1.21]}\end{array}$ & $\begin{array}{c}223.18 \\
{[212.04 ; 234.32]}\end{array}$ & $\begin{array}{c}119.85 \\
{[111.69 ; 128.01]}\end{array}$ & $\begin{array}{c}0.53 \\
{[0.51 ; 0.55]}\end{array}$ \\
\hline
\end{tabular}

aHS -1 and HS-2, and FS-1 and FS-2 refer to half-sib and full-sib progeny means with one and two generations of recombination, respectively. ${ }^{b}$ Confidence intervals between brackets at the $95 \%$ probability level.

enies is $\sigma_{G F S}^{2}=(1 / 2) \sigma_{A}^{2}+(1 / 4) \sigma_{D}^{2}$ and that of half-sib progenies is $\sigma_{G H S}^{2}=(1 / 4) \sigma_{A}^{2}$ ignoring epistasis and linkage disequilibrium; here $\sigma_{A}^{2}$ and $\sigma_{D}^{2}$ stand for additive and dominance variances, respectively (Hallauer \& Miranda Filho, 1988). The estimates of genetic variances did not differ $(p \leq 0.05)$ for both types of progenies subjected to one and two generations of recombination; i.e., $\hat{\sigma}_{G H S-1}^{2} \cong \sigma_{G H S-2}^{2}$ and $\hat{\sigma}_{G F S-1}^{2} \cong \sigma_{G F S-2}^{2}$, for all traits evaluated, except for prolificacy and ear placement for the half-sib progenies. For grain yield, plant height and ear height, all estimates of the heritability coefficients differed from zero for both types of progenies subjected to one and two generations of recombination, and the full-sib estimates were greater than the half-sib estimates as expected; however, for ear placement and prolificacy, three and one heritability 
estimates did not differ from zero, respectively. Disregarding these traits, the estimates of heritability coefficients did not differ between generations of recombination for the two types of progenies for grain yield, plant height and ear height; i.e., $\hat{h}_{H S-1}^{2} \cong \hat{h}_{H S-2}^{2}$ and $\hat{h}_{F S-1}^{2} \cong \hat{h}_{F S-2}^{2}$. Thus, one additional generation of recombination did not change the estimates of the genetic variances and of heritability coefficients (Table $3)$.

The two types of progenies subjected to one and two generations of recombination presented similar values and significances for the genetic correlations between the traits assessed, suggesting that one additional generation of recombination did not change the magnitudes of the genetic correlations. Also, genetic and phenotypic genetic correlations had similar values and significances for all traits, suggesting that environmental effects and progeny by environment interaction were of minor importance on the correlation between the traits assessed. Grain yield was highly correlated with prolificacy $\left(0.63 \leq \mathrm{r}_{\mathrm{G}} \leq 0.73\right)$ as expected because prolificacy is a grain yield component, moderately correlated with plant height $\left(0.42 \leq \mathrm{r}_{\mathrm{G}} \leq\right.$
$0.50)$, loosely correlated with ear height $\left(0.31 \leq \mathrm{r}_{\mathrm{G}} \leq\right.$ $0.39)$ and with ear placement $\left(0.22 \leq \mathrm{r}_{G} \leq 0.33\right)$. Prolificacy was not correlated with plant height, ear height, and ear placement. Plant and ear height was highly correlated $\left(0.87 \leq \mathrm{r}_{\mathrm{G}} \leq 0.97\right)$; plant height and ear height was moderately $\left(0.45 \leq \mathrm{r}_{\mathrm{G}} \leq 0.57\right)$ and highly $(0.67 \leq$ $\left.\mathrm{r}_{\mathrm{G}} \leq 0.76\right)$ correlated with ear placement, respectively (Table 4).

Recurrent selection programs are devised to be conducted for a long-term, and thus the genetic variability of the traits under selection should be maintained at such level that the magnitudes of the selection responses will remain high throughout the cycles. However, selection generates negative gametic phase linkage disequilibrium and as a consequence the genetic variance of the traits under selection will be reduced (Bulmer, 1980). The additive genetic variance after one cycle of truncated selection followed by one generation of recombination of the selected genotypes $\left(\sigma_{A 1}^{2}\right)$ is (Bulmer, 1980): $\sigma_{A 1}^{2}=(1 / 2)\left(1-h^{2} k\right) \sigma_{A 0}^{2}+(1 / 2) \sigma_{A 0}^{2} ; k=i(i-x)$, and $h^{2}$, $i, x$, and $\sigma_{A 0}^{2}$ stand for the heritability coefficient associated with the breeding procedure, the standardized

Table 3 - Estimates of genetic variances $\left(\hat{\sigma}_{G}^{2}\right)$, genetic by environment interactions $\left(\hat{\sigma}_{G E}^{2}\right)$, and heritability coefficients $\left(\hat{h}^{2} \%\right)$ for several traits of half- and full-sib progenies with one and two generations of recombination for EPB-4 maize population.

\begin{tabular}{|c|c|c|c|c|c|c|c|}
\hline Trait & Progeny ${ }^{a}$ & $\hat{\sigma}_{G}^{2}$ & C. I. & $\hat{\sigma}_{G E}^{2}$ & C. I. & $\hat{h}^{2} \%$ & C. I. \\
\hline \multirow{4}{*}{$\begin{array}{l}\text { Grain yield } \\
\text { (g per plant) }\end{array}$} & HS-1 & 123.40 & {$[77.71 ; 225.68]$} & -- & -- & 56.36 & {$[38.82 ; 69.50]$} \\
\hline & $\mathrm{HS}-2$ & 81.48 & {$[44.46 ; 195.24]$} & 43.03 & {$[13.81 ; 598.19]$} & 42.19 & {$[28.94 ; 59.60]$} \\
\hline & FS-1 & 167.68 & {$[107.08 ; 299.61]$} & 67.28 & {$[27.94 ; 325.55]$} & 58.34 & {$[41.59 ; 70.89]$} \\
\hline & FS-2 & 155.53 & {$[99.32 ; 277.90]$} & 45.77 & {$[14.69 ; 636.28]$} & 58.01 & {$[41.13 ; 70.66]$} \\
\hline \multirow{4}{*}{$\begin{array}{l}\text { Prolificacy } \\
(\text { ears per plant })^{b}\end{array}$} & HS- 1 & 0.17 & {$[0.07 ; 0.70]$} & -- & -- & 29.82 & {$[11.60 ; 50.95]$} \\
\hline & $\mathrm{HS}-2$ & -0.12 & {$[-0.04 ; 1.67]$} & 0.43 & {$[0.20 ; 1.58]$} & -- & -- \\
\hline & FS-1 & 0.20 & {$[0.06 ; 2.78]$} & 0.65 & {$[0.36 ; 1.51]$} & 21.51 & {$[9.69 ; 45.33]$} \\
\hline & FS-2 & 0.35 & {$[0.18 ; 0.95]$} & 0.19 & {$[0.05 ; 7.60]$} & 38.04 & {$[12.93 ; 56.60]$} \\
\hline \multirow{4}{*}{$\begin{array}{l}\text { Plant height } \\
\text { (cm per plant) }\end{array}$} & HS- 1 & 15.58 & {$[7.11 ; 57.17]$} & 0.97 & {$[0.19 ; 970.00]$} & 32.35 & {$[15.16 ; 52.73]$} \\
\hline & HS-2 & 23.14 & {$[12.16 ; 60.16]$} & 9.55 & {$[1.90 ; 9.55]$} & 39.50 & {$[15.18 ; 57.72]$} \\
\hline & FS- 1 & 53.83 & {$[36.29 ; 88.14]$} & -- & -- & 66.34 & {$[52.81 ; 76.48]$} \\
\hline & FS-2 & 43.77 & {$[28.47 ; 75.82]$} & -- & -- & 60.65 & {$[44.82 ; 72.59]$} \\
\hline \multirow{4}{*}{$\begin{array}{l}\text { Ear height } \\
\text { (cm per plant) }\end{array}$} & HS- 1 & 9.52 & {$[4.34 ; 34.94]$} & 11.98 & {$[5.24 ; 49.62]$} & 32.65 & {$[15.59 ; 52.94]$} \\
\hline & HS-2 & 10.26 & {$[5.28 ; 27.98]$} & 0.83 & {$[0.17 ; 830.00]$} & 39.19 & {$[14.75 ; 57.51]$} \\
\hline & FS-1 & 22.69 & {$[14.49 ; 40.54]$} & 1.92 & {$[0.38 ; 1,920.00]$} & 58.22 & {$[41.44 ; 70.81]$} \\
\hline & FS-2 & 20.09 & {$[12.46 ; 37.74]$} & 3.15 & {$[0.63 ; 3,150.00]$} & 54.62 & {$[36.37 ; 68.29]$} \\
\hline \multirow{4}{*}{ Ear placement ${ }^{\mathrm{c}}$} & HS- 1 & 0.69 & {$[0.33 ; 2.30]$} & 0.44 & {$[0.12 ; 17.60]$} & 33.66 & [7.09; 53.69] \\
\hline & HS-2 & 0.05 & {$[0.01 ; 0.50]$} & -- & -- & 4.39 & {$[-34.41 ; 33.01]$} \\
\hline & FS-1 & 0.43 & {$[0.15 ; 3.58]$} & 0.69 & {$[0.25 ; 5.75]$} & 22.99 & {$[-8.30 ; 46.02]$} \\
\hline & FS-2 & 0.49 & {$[0.18 ; 4.08]$} & 0.94 & {$[0.41 ; 3.89]$} & 24.26 & {$[-6.36 ; 46.99]$} \\
\hline
\end{tabular}

${ }^{a}$ HS-1 and HS-2, and FS-1 and FS-2 refer to half-sib and full-sib progenies with one and two generations of recombination, respectively.

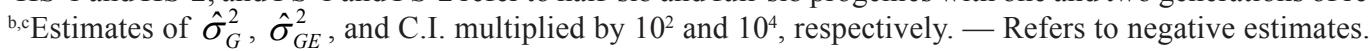


Table 4 - Genetic (above diagonal) and phenotypic (below diagonal) correlations among five traits of half-sib and full-sib progenies with one and two generations of recombination.

\begin{tabular}{|c|c|c|c|c|c|c|}
\hline Trait & Progeny/Rec. ${ }^{a}$ & Grain yield & Prolificacy & Plant height & Ear height & Ear placement \\
\hline \multirow{4}{*}{ Grain yield } & HS- 1 & & $0.73 * *$ & $0.49 * *$ & $0.39 * *$ & $0.33 * *$ \\
\hline & HS-2 & & -- & $0.47 * *$ & $0.31 * *$ & $0.29^{\mathrm{ns}}$ \\
\hline & FS-1 & & $0.66 * *$ & $0.42 * *$ & $0.34 * *$ & $0.26^{*}$ \\
\hline & FS-2 & & $0.63 * *$ & $0.50 * *$ & $0.34 * *$ & $0.22^{\text {ns }}$ \\
\hline \multirow{4}{*}{ Prolificacy } & HS-1 & $0.53 * *$ & & $0.17^{\mathrm{ns}}$ & $0.25^{\mathrm{ns}}$ & $0.18^{\mathrm{ns}}$ \\
\hline & HS-2 & $0.49 * *$ & & -- & -- & -- \\
\hline & FS-1 & $0.45 * *$ & & $0.09^{\text {ns }}$ & $0.14^{\mathrm{ns}}$ & $0.11^{\mathrm{ns}}$ \\
\hline & FS-2 & $0.49 * *$ & & $0.07^{\text {ns }}$ & $0.20^{\mathrm{ns}}$ & $0.06^{\text {ns }}$ \\
\hline \multirow{4}{*}{ Plant height } & HS- 1 & $0.35 * *$ & $0.12^{\text {ns }}$ & & $0.87 * *$ & $0.51 * *$ \\
\hline & HS-2 & $0.28 * *$ & $0.07^{\mathrm{ns}}$ & & $0.97 * *$ & $0.58 * *$ \\
\hline & FS-1 & $0.34 * *$ & $0.06^{\mathrm{ns}}$ & & $0.98 * *$ & $0.45 * *$ \\
\hline & FS-2 & $0.36 * *$ & $0.05^{\mathrm{ns}}$ & & $0.97 * *$ & $0.57 * *$ \\
\hline \multirow{4}{*}{ Ear height } & HS- 1 & $0.31 * *$ & $0.19^{\mathrm{ns}}$ & $0.81 * *$ & & $0.67 * *$ \\
\hline & HS-2 & $0.27 * *$ & $0.11^{\mathrm{ns}}$ & $0.89 * *$ & & $0.76 * *$ \\
\hline & FS-1 & $0.30 * *$ & $0.10^{\mathrm{ns}}$ & $0.88 * *$ & & $0.67 * *$ \\
\hline & FS-2 & $0.29 * *$ & $0.10^{\mathrm{ns}}$ & $0.88 * *$ & & $0.73 * *$ \\
\hline \multirow{4}{*}{ Ear Placement } & HS- 1 & $0.19^{\mathrm{ns}}$ & $0.16^{\mathrm{ns}}$ & $0.21 *$ & $0.73 * *$ & \\
\hline & HS-2 & $0.13^{\mathrm{ns}}$ & $0.08^{\mathrm{ns}}$ & $0.24 *$ & $0.63 * *$ & \\
\hline & FS- 1 & $0.16^{\mathrm{ns}}$ & $0.09^{\mathrm{ns}}$ & $0.21 *$ & $0.65 * *$ & \\
\hline & FS-2 & $0.13^{\text {ns }}$ & $0.05^{\mathrm{ns}}$ & $0.26 * *$ & $0.68 * *$ & \\
\hline
\end{tabular}

${ }^{a}$ HS-1 and HS-2, and FS-1 and FS-2 refer to half-sib and full-sib progeny with one and two generations of recombination, respectively. ns;";** Non-significant, and significant at the 0.05 and 0.01 probability levels, respectively. ${ }^{-}$Not computed because of negative estimate of genetic variance.

selection intensity, the deviation of the point of truncation from the population mean, and the original additive variance. The additive variance is then reduced by $-(1 / 2) h^{2} k \sigma_{A 0}^{2}$, which depends on the intensity of selection and of the heritability coefficient; and $(1 / 2) \sigma_{A 0}^{2}$ is the restored part of the additive variance due to one generation of recombination of the unlinked loci; thus higher the intensity of selection higher the linkage disequilibrium and higher the reduction of the magnitude of the additive variance.

When selection is relaxed at the $t$ th generation, $k=0$ and the additive genetic variance will increase by the following recurrent equation $\sigma_{A t}^{2}=(1 / 2) \sigma_{A(t-1)}^{2}+(1 / 2) \sigma_{A 0}^{2}$, and after several generations of recombination the additive variance of the selected population will reach the original value (Bulmer, 1980). Thus, as only one generation of recombination has been used in recurrent selection programs (Hallauer, 1985), the linkage disequilibrium, even for unlinked loci, is not totally dissipated; and then one could expect that the magnitudes of the genetic variances and of the responses to selection will be reduced in the succeeding cycles of selection. Hence, if genetic variances are expected to be reduced in populations undergoing re- current selection programs and if only one generation of recombination could not dissipate the linkage disequilibrium, one important question is whether one additional generation of recombination; i.e., two generations of recombination, could lessen the linkage disequilibrium at such extent that the increase in the magnitude of the additive genetic variance and consequently in the response to selection would compensate the extra-time spent with another generation of recombination. Based on Bulmer's theory, one could expect that further recombination of the selected progenies would change the distribution of the genotypes, increasing the genetic variances because of the reduction of the linkage disequilibrium, and then transgressive genotypes for traits of interest would be generated allowing the selection of outstanding genotypes.

Although restricted to only one additional generation of recombination, the results of our study did not support this expectation for recurrent selection programs in maize, because there were not significant differences between HS-1 and HS-2 progenies, and also between FS-1 and FS-2 progenies for the means, ranges, estimates of genetic variances, heritability coefficients, genetic correlations, and for the distribution 
of the means, for most of the traits assessed. For instance, for grain yield, the most important trait in maize breeding programs, the HS-1 progenies ranged from $118.90 \mathrm{~g}$ per plant to $186.96 \mathrm{~g}$ per plant, and for HS2 they ranged from $118.97 \mathrm{~g}$ per plant to $184.89 \mathrm{~g}$ per plant; and for FS-1 the progenies ranged from 110.56 g per plant to $198.72 \mathrm{~g}$ per plant, and for FS-2 they ranged from $105.32 \mathrm{~g}$ per plant to $196.46 \mathrm{~g}$ per plant. Therefore, the population random-mated twice did not generate transgressive progenies with greater grain yields than the population with only one generation of recombination for the two types of progenies.

Studies conducted in recurrent selection programs with soybean (Piper \& Fehr, 1987; Guimarães $\&$ Fehr, 1989) have also shown that more than one generation of intermating of the selected progenies did not change the genetic properties of the populations, which is in agreement with our results. Thus, our results strongly suggest that only one additional generation of recombination of selected progenies from recurrent selection is not enough to change the genetic properties of the improved populations and, therefore, an additional generation of recombination will not increase the effectiveness of maize recurrent selection programs.

\section{REFERENCES}

BETRÁN, F.J.; HALLAUER, A.R. Hybrid improvement after reciprocal recurrent selection in BSSS and BSCB1 maize populations. Maydica, v.41, p.25-33, 1996.

BULMER, M.G. The mathematical theory of quantitative genetics. Oxford: Clarendon Press, 1980. 254p.

BURDICK, R.K.; GRAYBILL, F.A. Confidence intervals on variance components. New York: Marcel Dekker, 1992. 211p.
GUIMARÃES, E.P.; FEHR, W.R. Alternative strategies of recurrent selection for seed yield of soybean. Euphytica, v.40, p.111$120,1989$.

HALLAUER, A.R. Compendium of recurrent selection methods and their application. Critical Review of Plant Science, v.3, p.1-34, 1985.

HALLAUER, A.R.; MIRANDA FILHO, J.B. Quantitative genetics in maize breeding. Ames: Iowa State University Press, 1988. 468p.

HALLAUER, A.R.; RUSSEL, W.A.; LAMKEY, K.R. Corn breeding. In: SPRAgue, G.F.; DUdLeY, J.W. (Ed.) Corn and Corn improvement. Madison: American Society of Agronomy, 1988, Cap.8, p.463-564.

PIPER, T.E.; FEHR, W.R. Yield improvement in a soybean population by utilizing alternative strategies of recurrent selection. Crop Science, v.27, p.172-178, 1987.

REZENDE, G.S.P.; SOUZA JÚNIOR, C.L. A reciprocal recurrent selection procedure outlined to integrate hybrid breeding programs in maize. Journal of Genetics and Breeding, v.54, p. 57-66, 2000.

SANTOS, M.F.; MORO, G.V.; AGUIAR, A.M.; SOUZA JÚNIOR, C.L. Responses to reciprocal recurrent selection and changes in genetic variability in IG-1 and IG-2 maize populations. Genetics \& Molecular Biology, v.28, p.781-788, 2005.

SAS INSTITUTE. SAS ${ }^{\mathbb{1}}$ proprietary software: version 9.1. Cary: SAS Institute, 2004.

SEARLE, S.R.; CASELLA, G.; McCULLOCH, C.E. Variance components. New York: John Wiley, 1992. 501p.

SHAPIRO, S.S.; WILK, M.B. An analysis of variance test for normality (complete samples). Biometrika, v.52, p.591-611, 1965.

SNEDECOR, G.W.; COCRHAN, W.G. Statistical methods. Ames: Iowa State University Press, 1989. 503p.

SOUZA JÚNIOR, C.L.; PINTO, R.M.C. Responses to a shortterm reciprocal recurrent selection procedure in maize. Maydica, v. 45, p. $21-28,2000$.

VENCOVSKY, R.; BARRIGA, P. Genética biométrica no fitomelhoramento. Ribeirão Preto: Sociedade Brasileira de Genética, 1992. 486p.

Received December 18, 2007

Accepted June 24, 2008 